\title{
Genetic Variability and Character Association in Maize (Zea mays L.) Inbred Lines
}

\author{
Md. Al-Amin 1,a , Md. Abul Kalam Azad ${ }^{1, b}$, Shahriar Rahman Shovon ${ }^{1, c, *}$, Most. Farzana Haque ${ }^{2, d}$ \\ ${ }^{1}$ Department of Genetics and Plant Breeding, Hajee Mohammad Danesh Science and Technology University, Dinajpur 5200, Bangladesh \\ ${ }^{2}$ Faculty of Agriculture, Hajee Mohammad Danesh Science and Technology University, Dinajpur 5200, Bangladesh \\ "Corresponding author

\begin{tabular}{|c|c|}
\hline A R T I CLE INFO & A B S T R A C T \\
\hline $\begin{array}{l}\text { Keywords: } \\
\text { Heritability } \\
\text { Genotypic coefficient of variance } \\
\text { Genetic advance } \\
\text { Heterosis } \\
\text { Direct effect }\end{array}$ & $\begin{array}{l}\text { Maize grain yield is a complicated character which depends on multiple factors. Considering this } \\
\text { aspect, we carried out an experiment to estimate the genetic parameters and character association of } \\
\text { thirty inbred line in maize during November } 2017 \text { to April } 2018 \text {. The highest genotypic coefficient } \\
\text { of variation (GCV) was observed for a Number of kernel row per ear (NKRE), ear diameter (ED), } \\
\text { plant height (PH), number of kernels per row (NKR). However, heritability (percentage) exhibited } \\
\text { highest for the yield per plant (YP), thousands kernel weight (TKW), cob weight (CW), first ear } \\
\text { height (FEH), ear length (EL). The percentage of genetic advance (GAM\%) was high for YP, CW, } \\
\mathrm{PH}, \mathrm{FEH}, \mathrm{TKW} \text {. Results demonstrated that EL has a significant positive correlation with NKR }(\mathrm{r}= \\
\left.0.661^{* *}\right) \text {. YP showed significant positive correlation with PH }\left(\mathrm{r}=0.718^{* *}\right) \text {. While EL }\left(\mathrm{r}=0.587^{* *}\right) \text {, } \\
\mathrm{NKR}\left(\mathrm{r}=0.501^{* *}\right) \text {, NKE }\left(\mathrm{r}=0.422^{* *}\right) \text {, and TKW }\left(\mathrm{r}=0.612^{* *}\right) \text { showed insignificant association } \\
\text { with YP }(0.718) \text {. YP has insignificant association with EL to NKRE }(\mathrm{r}=-0.0414) \text { and PH to FEH }(\mathrm{r} \\
=-0.092) \text {. Highest and positive direct effect on YP was exhibited by TKW }(0.519) \text {. Considering all } \\
\text { traits, IL-28, performed better followed by IL-9, IL-15, and IL-10. The development of hybrids } \\
\text { genotypes, these genotypes have the chance to obtain higher heterosis with high performing crosses. }\end{array}$ \\
\hline
\end{tabular}

\section{Introduction}

Maize is the world's most widely grown crop after rice and wheat, and it is the primary staple food in many developing countries (Morris et al., 1999). This year (20172018) estimated corn production is $1,033.7$ million tons in the world (USDA, 2018). In Bangladesh, recently its cultivation is gaining popularity and occupied the second position next to rice in the preceding year (DAE, 2012) as the requirement of maize grain is being increased as poultry industry flourishes in Bangladesh and is the most demandable cereal food of the poultry industry in Bangladesh (Zaman and Alam, 2013).

Last five years, maize was produced in 350000 ha with the production of 2.3 million metric tons with an average yield of maize is $6.6 \mathrm{t} \mathrm{ha}^{-1}$ in Bangladesh (BBS, 2016). Maize production for last ten years has been increased by more than twelve times due to its high demand in the local markets. Bangladesh produces about 3.1 million metric tons of maize in 2017-2018 with the area of 4.40 million ha.

Maize has a significant role in human and livestock nutrition worldwide (Ahmed et al., 2011). It is used as a raw material in medicine, food, textile industries, etc. Moreover, maize crop serves as a source of basic raw material for several industries such as starch, protein, oil, alcoholic beverages, food, sweeteners, cosmetics, and biofuels (Khan and Dubey, 2015). Therefore, stem and foliage of maize plant can be used as livestock feed. Stalk, dry leaf covering of cobs (husks) and shelled cobs can be used as fuel (Ahmed et al., 2011).

Maize has similar calorie content like wheat and rice. It is obvious that if rice is partially replaced by maize in the diet, protein intake will be increased (Uddin et al., 2010). It contains 70-75\% starch, 2-8 \% protein etc. (Chaudhry et al., 1993).

The most limiting factor of maize research in Bangladesh is the development, improvement, and maintenance of parental or inbred lines. On the other hand, the problem of imported hybrid seed is the involvement of high price and uncontrolled quality. One important approach to improve this situation is the development of inbred lines which can produce high yielding hybrid varieties (Azad et al., 2012). 
The utility of heritability, therefore, increases when it is used to calculate genetic advance (GA), which indicates the degree of gain in character obtained under particular selection pressure. Thus, GA is an important selection parameter that aids the breeder in a selection program (Shukla et al., 2004). Information regarding interrelationships between quantitatively inherited plant traits and their direct and indirect effects on grain yield is of great importance for success in selections to be conducted in breeding programs (Khan et al., 2006). Using path coefficient (PC) analysis, it is easy to determine which yield component is influencing the yield substantially. Phenotypic coefficients of variations (PCV) and genotypic coefficients of variations (GCV), heritability and GA have been used to assess the magnitude of variance in the maize breeding material. Plant breeders have used PC analysis to assist in identifying traits that are used as selection criteria to improve crop yield (Garcia et al., 2003). Initiating a breeding program based on the yield components requires the knowledge of the relationship between the yield and its component characters. In this connection, determination of correlation of coefficient (CC) between the characters has a considerable importance in selecting breeding materials (Afroz et al., 2004). On the other hand, PC analysis has been found to give more specific information on the direct and indirect influence of each of the component characters upon grain yield.

The study of characters association along with heritability and genetic variability has been applied to major crops like rice (Allam et al., 2015), wheat (Singh et al., 2014), barley (Yadav et al., 2015), maize (Maruthi and Jhansi Rani, 2015), etc. The objective of this study is to investigate the genetic variability and correlation of morpho-physiological and yield traits in maize inbred lines. Therefore, the present study is undertaken to find out the relationship between yield and its component characters and the causes of such relations was further analysed.

\section{Materials and Methods}

Experimental Site, Geographical Location, and Plant Materials

The field experiment was carried out at the experimental plot of the Department of Genetics and Plant Breeding, Hajee Mohammad Danesh Science and Technology University (HSTU), Dinajpur, Bangladesh. Geographically the location is situated at $25^{\circ} 41^{\prime} \mathrm{N}$ latitude and $88^{\circ} 39^{\prime} \mathrm{E}$ latitude with an elevation of $37 \mathrm{~m}$ from sea level, during the period from November 2017 to April 2018 to study the variability and character association in maize (Zea mays L.). The land was medium high land, Himalayan Piedmont Plain Agro-ecological zone (AEZ-1), textured by sandy loam with $\mathrm{pH}$ of around 6.2 during the growing period. There are thirty maize inbred lines $\left(\mathrm{F}_{5}\right)$, (IL-1, IL2, IL-3, IL-4,IL-5, IL-6, IL-7, IL-8, IL-9, IL-10, IL-11, IL12, IL-13, IL-14, IL-15, IL-16, IL-17, IL-18, IL-19, IL-20, IL-21, IL-22, IL-23, IL-24, IL-25, IL-26, IL-27, IL-28, IL29 , IL-30), and each of the genotypes was obtained in the 2016-2017 cropping seasons, and purity and genotype percentage was above $98 \%$, which was collected from the Department of Genetics and Plant Breeding, HSTU, Dinajpur, Bangladesh. The experiment was laid out in the randomized complete block design (RCBD) with three replications.

\section{Cultural Operations}

The plot of the experiment was prepared in November 2017, and green manure and decomposed organic matter were used at the rate of $6.0 \mathrm{t} \mathrm{ha}^{-1}$ before final land preparation. The chemical fertilizer such as urea, muriate of potash, gypsum, boric acid and zinc sulphate were applied in the plot at the rate of 50, 195, 100, 10 and $10 \mathrm{~kg}$ $\mathrm{ha}^{-1}$, respectively as basal dose. The rest $120 \mathrm{~kg} \mathrm{ha}^{-1}$ urea was applied in three equal splits (i.e. $40 \mathrm{~kg} / \mathrm{splits)}$ at 25,45 and 60 days after planting as side dressing 3 to $5 \mathrm{~cm}$ away from the plat and the furrow of the fertilizer are filled up immediately. At the same time third dressing of urea, rest $35 \mathrm{~kg} \mathrm{ha}^{-1}$ of muriate of potash were used. The standard agronomic practices were followed (Quayyum et al., 1993) in this experiment. After 50 days of planting, chloropyriphose was sprayed against sucking pests such as jassid and aphid.

\section{Data Analysis}

Observation on inherited traits was recorded quantitatively on ten (FEH, PH, EL, ED, NKRE, NKR, NKE, TKW, YP, CW) yield and physio-morphological traits from competitive randomly selected plants. Mean data were statistically analysed for each character separately. The significance of the difference among the genotypes of means was estimated by the Duncan's Multiple Range Test (DMRT) test at 5\% level of probability (Gomez and Gomez, 1984). Correlation coefficient (CC) (Singh and Chaudhury, 1985), components of variance (CV) (Johnson et al., 1955), genotypic coefficient of variance (GCV), phenotypic coefficient of variance (PCV) (Burton, 1952), heritability $\left(\mathrm{H}^{2} \mathrm{~b}\right)$ (Jhonson et al., 1955; Hanson et al. 1956), genetic advance (GA) (Singh and Chaudhary, 2010), percentage of genetic advance of mean (GAM\%) (Comstock and Robinson, 1952), and simple correlation coefficients (SCC) (Singh and Chaudhary, 1985) were calculated. A PC is simply a standardized partial-regression co-efficient and as such measures the direct influence of one variable upon another and permits the separation of the correlation coefficient into components of direct and indirect effects (Wright, 1923) and PC was estimated (Dewey, 1959).

\section{Results and Discussion}

The experiment was conducted to analyse the genetic variation and yield potential of thirty maize genotypes. Mean performance and other analyses were done on ten yield and yield contributing characters are FEH, PH, EL, ED, NKRE, NKR, NKE, TKW, YP, EW.

\section{Analysis of Variance for Different Yield and Yield Contributing Characters}

Analysis of variance in Table 1 showed significant mean squares for all characters. Analysis indicated significant differences among the varieties for all characters. Significant genotype variances were observed for FEH, PH, EL, ED, NKRE, NKR, NKE, TKW, YP, CW. Analysis of variance demonstrated that genotypes were possessing inherent genetic variances among themselves with respect to the characters studied and the mean squares against the replications found significant for all the characters. 
Table 1 Analysis of variance (mean square) of yield and yield contributing character of thirty maize inbred lines

\begin{tabular}{l|ccccccccccc}
\hline \multirow{2}{*}{ Source of variation } & \multirow{2}{*}{ df } & \multicolumn{1}{c}{ Mean square } \\
\cline { 2 - 12 } & & FEH & PH & EL & ED & NKRE & NKR & NKE & TKW & YP & CW \\
\hline Genotypes & 29 & $500.9^{* *}$ & $1431.0^{* *}$ & $14.1^{* *}$ & $4.4^{* *}$ & $4.81^{* *}$ & $41.2^{* *}$ & $8683.6^{* *}$ & $16072.1^{* *}$ & $2963^{* *}$ & $424.4^{* * *}$ \\
Replication & 2 & 183.55 & 185.93 & 5.11 & 0.43 & 2.51 & 1.18 & 353.2 & 5861.1 & 214.44 & 6.23 \\
Error & 58 & 16.07 & 18.84 & 2.08 & 0.49 & 2.05 & 11.22 & 2439.8 & 2108.2 & 304.49 & 3.71 \\
CV $(\%)$ & & 6.23 & 2.38 & 9.15 & 4.88 & 10.12 & 15.36 & 15.61 & 12.96 & 15.86 & 5.32 \\
\hline
\end{tabular}

df, Degree of freedom; FEH, First Ear Hight; PH, Plant Height; EL, Ear Length; ED, Ear Diameter; NKRE, Number of kernel row per ear; NKR, Number of Kernel per Row; NKE, Number of Kernels per Cob; TKW, Thousand Kernel Weight; YP, Yield per Plant; CW, Pith Weight, * indicate 5\% level of significant and $* *$ indicate $1 \%$ level of significant

Table 2 Estimation of variance for various characters in maize

\begin{tabular}{l|ccr}
\hline \multirow{2}{*}{ Characters } & \multicolumn{3}{c}{ Variances } \\
\cline { 2 - 4 } & Genotype & Phenotype & Environmental \\
\hline FEH & 7.97 & 13.33 & 2.07 \\
PH & 13.19 & 2.47 & 18.84 \\
EL & 3.97 & 22.13 & 0.49 \\
ED & 3.80 & 1.34 & 2.05 \\
NKRE & 3.76 & 1.72 & 11.22 \\
NKR & 4.69 & 4.61 & 2439.8 \\
NKE & 17.55 & 67.24 & 2108.2 \\
TKW & 18.65 & 82.24 & 304.49 \\
YP & 10.42 & 34.51 & 3.71 \\
PWT & 6.07 & 11.99 & \\
\hline
\end{tabular}

FEH, First Ear Hight; PH, Plant Height; EL, Ear Length; ED, Ear Diameter; NKRE, Number of kernel row per ear; NKR, Number of Kernel per Row; NKE, Number of Kernels per Cob; TKW, Thousand Kernel Weight; YP, Yield per Plant; CW, Pith Weight

Table 3 Estimation of CV, CV\% heritability in the broad sense, GA and GAM\% for various characters in maize

\begin{tabular}{|c|c|c|c|c|c|c|c|}
\hline \multirow{2}{*}{ Characters } & \multicolumn{2}{|c|}{ Coefficients of variation } & \multicolumn{2}{|c|}{ Coefficients of variation $(\%)$} & \multirow{2}{*}{ HBS } & \multirow{2}{*}{ GA } & \multirow{2}{*}{ GAM } \\
\hline & Genotypic & Phenotypic & Genotypic & Phenotypic & & & \\
\hline FEH & 0.12 & 0.21 & 12.54 & 20.98 & 90.96 & 2497.7 & 39.30 \\
\hline $\mathrm{PH}$ & 0.07 & 0.01 & 7.58 & 1.42 & 65.83 & 334.62 & 1.92 \\
\hline EL & 0.25 & 1.40 & 25.18 & 14.31 & 66.15 & 4386.3 & 277.91 \\
\hline ED & 0.26 & 0.09 & 26.34 & 9.30 & 72.49 & 200.15 & 13.89 \\
\hline NKRE & 0.26 & 0.12 & 26.58 & 12.18 & 30.84 & 109.39 & 7.73 \\
\hline NKR & 0.21 & 0.21 & 21.31 & 20.91 & 47.12 & 447.04 & 20.29 \\
\hline NKE & 0.06 & 0.22 & 5.70 & 21.83 & 46.03 & 6376.3 & 20.70 \\
\hline TKW & 0.05 & 0.24 & 5.36 & 23.64 & 68.83 & 11659 & 33.51 \\
\hline YP & 0.09 & 0.32 & 9.60 & 31.81 & 74.43 & 5290.4 & 48.77 \\
\hline $\mathrm{CW}$ & 0.16 & 0.32 & 16.46 & 32.52 & 97.42 & 2407.8 & 65.25 \\
\hline
\end{tabular}

HBS: Heritability in the broad sense (\%), GA: Genetic advance, GAM: Genetic advance in (\%) mean

\section{First Ear Height}

The ear which first appeared on the plant that length is called first ear length (FEH). The mean of FEH was 61.83 and highest was 78.4 and lowest was 52.3. Analysis of variance showed the significant difference (at $1 \%$ level). The PV (13.33) was moderately higher than the GV (7.97) indicating the comparatively less environmental effect of FEH (Table 2). The character showed moderate GC (12.54) and PCV (20.98) and high heritability in the broad sense (90.96) along with moderate GAM\% (39.30) (Table 3). Moderate PCV and GCV was observed for FEH that was similar to Farina et al. (2015) and the expected heritability was high for FEH.

\section{Plant Height}

PV (22.13) was not much higher than GV (3.97) showing a lack of considerable environmental influence on this character (Table 2). Moderate GCV (12.54) with high heritability (96.15) and high GAM\% (277.91) indicated that there was a high scope to isolate good genotypic for this character in the present material (Table 3). It was reported that heritability, $\mathrm{CV}$, and $\mathrm{GA}$ values were computed for PH that was similar to Rafique et al. (2006).

\section{Ear Length}

PV (2.47) was not much higher than GV (2.08) indicating the comparatively less environmental effect of this trait (Table 2). The character showed moderate GCV (4.46) and PCV and moderate heritability in the broad sense (59.09) along with the moderate GAM\% (7.08) (Table 3). This indicated the moderate scope of selection for the EL. These findings were in agreement with the results obtained by other research Matin et al. (2017).

\section{Ear Diameter}

PV (1.34) was moderately lower than GV (3.80) indicating the comparatively less environmental effect of this trait (Table 2). The character showed higher GCV (26.34) and PCV (9.30) and high heritability in the broad sense (72.49) along with the moderate GAM\% (13.89) (Table 3). This indicated the moderate scope of selection for the ED.

\section{Row Number Per Ear}

The difference between GV (3.76) and PV (1.72) was low indicating the low environmental influence on this trait 
(Table 2). Moderate GCV (26.58) and PCV (12.18) were observed in NKRE. The lowest heritability in the broad sense (30.84) along with high GA in the percentage of the mean (7.73) (Table 3).

\section{Number of Kernels Per Row}

These observations are in conformity with the findings of NKR (Matin et al., 2017). PV (4.61) was not much lower than GV (4.69) indicating the comparatively less environmental effect of NKR (Table 2). The character showed less GCV (21.31) and PCV (20.91) and medium heritability in the broad sense (47.12) along with medium GAM\% (20.29) (Table 3).

\section{Number of Kernels Per Ear}

PV of total NKE (67.24) was much higher than GV (17.55) and environmental variation indicating the considerable influence of environment on the NKE (Table 2). High GCV (5.70) and PCV (21.83) were obtained for NKE. GAM\% (20.70) was high. More or less similar results were also reported by Dawood and Mohamed (1997). Heritability estimate (46.03) was high (Table 3) that was similar to the previous study Ali et al. (2012); Moulin et al. (2009), This indicated better scope for the improvement of NKE through selection.

\section{Thousand Kernel Weight}

The difference between GV (0.05) and PV (0.24) was low indicating minimum environment influence on TKW (Table 2). Moderate GCV (5.36) and high PCV (23.64) were observed for TKW. Moderate heritability (68.83\%) with high GAM\% mean (33.51) was observed for TKW (Table 3). This indicated better scope for the improvement of TKW through selection and low heritability was evaluated for TKW by Begum et al. (2016).

\section{Yield Per Plant}

The difference between PV (34.51) and GV (10.42) was low indicating environment influence on YP (Table 2). The heritability estimates though provide the basis for selection on the phenotypic performance; Johnson et al. (1995) suggested that the estimates of heritability and GA should always be considered simultaneously. In the present study, GAM\% (48.77) for YP was moderately higher (Table 3). However, heritability estimates were high and significant for higher heritability estimates comparatively more effective in improving maize population for YP.

\section{Cob Weight}

The difference between GV (6.07) and PV (11.99) was low indicating minimum environment influence on $\mathrm{CW}$ (Table 2). Moderately high GCV (16.46) and high PCV (32.52) were also observed for CW. High heritability $(97.42 \%)$ with highest GAM\% mean (65.25) was also observed for CW (Table 3). This indicated better scope for the improvement of $\mathrm{CW}$ through selection.

\section{Correlation Study}

SCC among ten important yield and yield contributing characters were analysed to determine the component characters on which selection could be based for improvement in yield of thirty maize genotypes under consideration (Table 4). PH exhibited significant positive association with YP $\left(\mathrm{r}=0.718^{* *}\right)$, FEH $\left(0.550^{* *}\right), \mathrm{EL}$ $\left(0.801^{* *}\right)$, ED $\left(0.810^{* *}\right), \mathrm{NKR}\left(\mathrm{r}=0.721^{* *}\right)$, TKW $(\mathrm{r}=$ $\left.0.702^{* *}\right)$, NKE $\left(\mathrm{r}=0.615^{* *}\right)$. This result suggested that with the increase of PH, FEH, EL, ED, NKR, TKW, NKE will increase. On the other hand, $\mathrm{PH}$ showed nonsignificant positive association with NKRE $(r=0.083)$ (Table 4). It was reported that YP was positively and significantly correlated with PH. Sadek et al. (2006); Bello et al. (2010) observed significant positive correlation between PH and YP. EL exhibited significant excellent positive association with YP $\left(\mathrm{r}=0.801^{* *}\right)$, CW ( $\mathrm{r}=$ $\left.0.681^{* *}\right)$, NKR $(\mathrm{r}=0.661 * *)$ and TKW $(\mathrm{r}=0.617)$. On the other hand, the NKRE ( $\mathrm{r}=-0.0414)$ showed nonsignificant and negative association with EL. The NKRE has significant positive association with the NKE $(\mathrm{r}=$ $0.427 * *)$, NKR showed non-significant positive association with YP $(\mathrm{r}=0.083)$ and TKW $(\mathrm{r}=-0.246)$. These results suggested that with the increase of NKRE, YP and CW not increased. TKW showed a non-significant negative relationship with NKRE (Table 4). NKR had significant positive association with $\mathrm{YP}\left(\mathrm{r}=0.721^{* *}\right)$. NKR had significant positive association with NKE $\left(0.836^{* *}\right)$. This result indicated that with the increase of NKE, TKW increases in a non- significant and positive way (Table 4). NKE showed significant positive association with YP $\left(\mathrm{r}=0.615^{* *}\right)$ and $\mathrm{CW}\left(0.493^{* *}\right)$. Table 4 exhibited significant positive association with NKE. TKW showed significant and positive association with both YP $\left(\mathrm{r}=0.702^{* *}\right)$ and $\mathrm{CW}\left(0.465^{* *}\right)$. This result suggested that with the increase of TKW, YP increases. TKW had significant positive association with CW ( $\mathrm{r}=$ $0.639 * *), \operatorname{NKR}(\mathrm{r}=0.501 * *), \operatorname{NKE}(\mathrm{r}=0.472 * *)$. Omikunle et al. (2006) suggested that TKW was positive association with YP (Table 4). FEH showed significant and positive association with $\mathrm{PH}\left(0.716^{* *}\right)$, EL $\left(0.342^{* *}\right)$, ED (0.496**), NKR (0.347**), TKW (0.593**), YP (0.550**). It may be concluded that YP increases with the increase of PH, EL, FEH, NKR, NKR, NKE, TKW, and CW.

\section{Path Coefficient Analysis of Yield Per Plant Vs Yield} Contributing Characters

Path coefficient analysis denotes the components of correlation co-efficient within different traits into the direct and indirect effects and indicates the relationship in more meaningful way. Path analysis revealed that FEH, EL, NKRE had negative direct effect on YP and those showed negligible negative indirect effect (Table 5). Positive indirect effects revealed through ED, PH, NKRE, NKR, NKE, TKW, and CW. On the other hand, path analysis (PA) revealed that ED, NKRE, NKR, NKE, TKW, CW, had positive direct effect on YP (Table 5). It showed negligible positive indirect effect through EL, ED, NKE and TKW and CW, whereas the NKR, FEH PH, NKRE showed negative indirect effect through the NKRE (Figure 1)

Results from the present study indicated that YP, PH, ED, NKR, FEH, CW, NKRE have high GCV. Heritability estimate was high for the character of FEH, CW, YP, ED followed by TKW, NKE, PH. The expected GAM\% was found to be high for ED and CW followed by PH, NKE, NKR. (Khan et al., 2006) reported that heritability estimates along with GAM\% were more valuable than the former alone in predicting the effect of selection. 


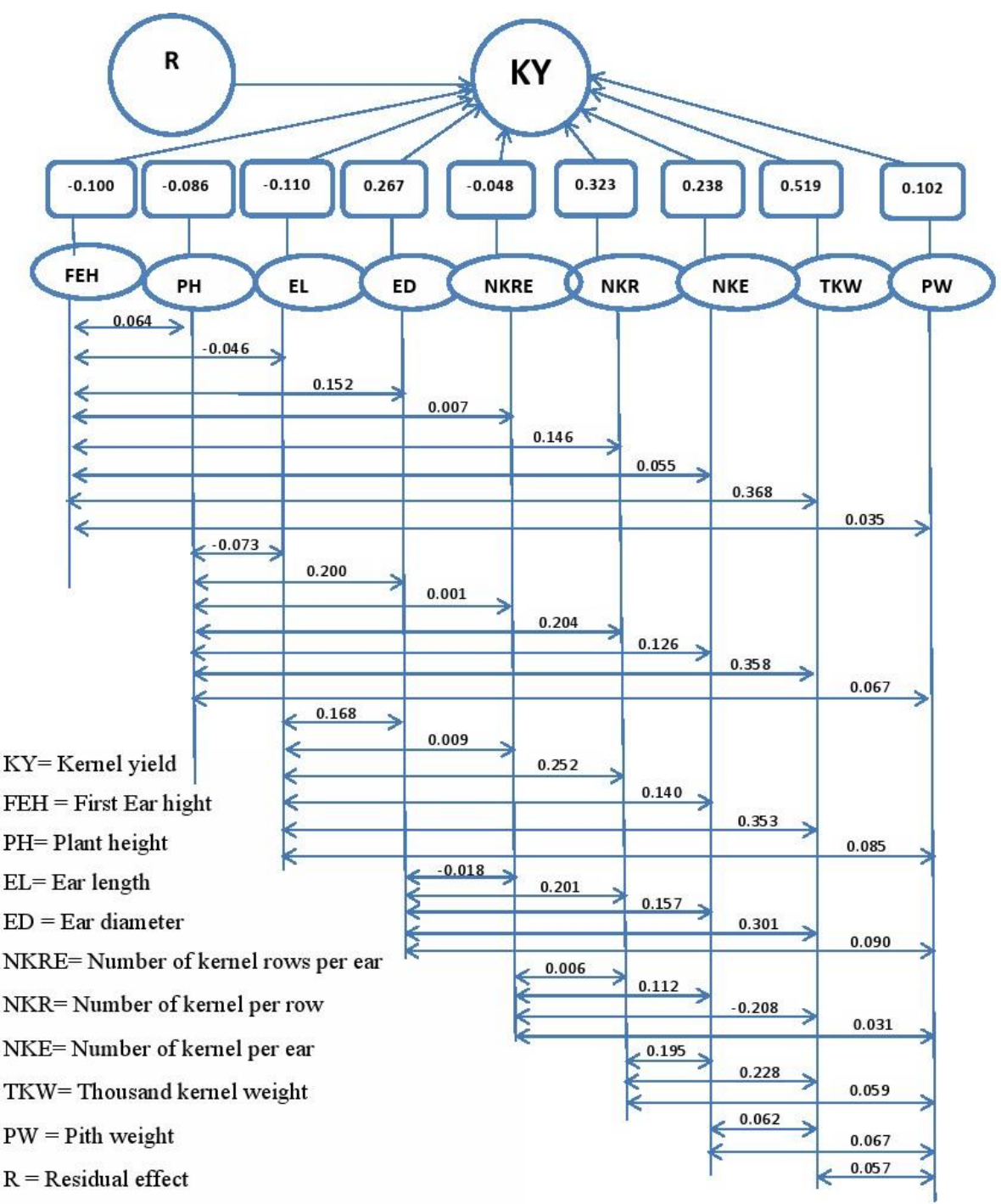

Figure 1 Path diagram showing yield contributing characters on YP in maize

Table 4 Genotypic $\mathrm{CC}$ among yield and yield contributing characters of maize

\begin{tabular}{l|cccccccccc}
\hline Characters & FEH & PH & EL & ED & NKRE & NKR & NKE & TKW & YP & PWT \\
\hline FEH & 1.00 & $0.71^{* *}$ & $0.34^{* *}$ & $0.49^{* *}$ & -0.09 & $0.35^{* *}$ & 0.19 & $0.59^{* *}$ & $0.55^{* *}$ & $0.31^{*}$ \\
PH & & 1.0 & $0.59^{* *}$ & $0.67^{* *}$ & -0.008 & $0.50^{* *}$ & $0.42^{* *}$ & $0.61^{* *}$ & $0.72^{* *}$ & $0.59^{* *}$ \\
EL & & & 1.00 & $0.59^{* *}$ & -0.04 & $0.66^{* *}$ & $0.53^{* *}$ & $0.61^{* *}$ & $0.80^{* *}$ & $0.68^{* *}$ \\
ED & & & & 1.00 & $0.42^{* *}$ & $0.54^{* *}$ & $0.61^{* *}$ & $0.52^{* *}$ & $0.81^{* *}$ & $0.74^{* *}$ \\
NKRE & & & & & 1.00 & 0.09 & $0.43^{* *}$ & -0.25 & 0.083 & 0.19 \\
NKR & & & & & & 1.00 & $0.84^{* *}$ & 0.23 & $0.72^{* *}$ & $0.45^{* *}$ \\
NKE & & & & & & & 1.00 & 0.023 & $0.62^{* *}$ & $0.49^{* *}$ \\
TKW & & & & & & & & 1.00 & $0.70^{* *}$ & $0.46^{* *}$ \\
YP & & & & & & & & & 1.00 & $0.69^{* *}$ \\
PWT & & & & & & & & & & 1.00 \\
\hline
\end{tabular}

Table 5 Direct and indirect effect of yield contributing characters on yield in thirty genotypes of maize

\begin{tabular}{l|cccccccccc}
\hline \multicolumn{1}{c}{ Characters } & FEH & PH & EL & ED & NKRE & NKR & NKE & TKW & YP & PWT \\
\hline FEH $(\mathrm{cm})$ & -0.100 & 0.064 & -0.046 & 0.152 & 0.007 & 0.146 & 0.055 & 0.368 & 0.035 & 0.550 \\
PH $(\mathrm{cm})$ & -0.074 & -0.086 & -0.073 & 0.200 & 0.001 & 0.204 & 0.126 & 0.358 & 0.067 & 0.718 \\
EL $(\mathrm{cm})$ & -0.042 & -0.057 & -0.110 & 0.168 & 0.009 & 0.252 & 0.140 & 0.353 & 0.085 & 0.801 \\
ED $(\mathrm{cm})$ & -0.057 & -0.064 & -0.069 & 0.267 & -0.018 & 0.201 & 0.157 & 0.301 & 0.090 & 0.810 \\
NKRE & 0.0034 & 0.001 & 0.020 & 0.101 & -0.048 & 0.006 & 0.112 & -0.208 & 0.031 & 0.083 \\
NKR & -0.0103 & -0.054 & 0.086 & 0.166 & -0.001 & 0.323 & 0.195 & 0.228 & 0.059 & 0.721 \\
NKE & -0.045 & -0.045 & -0.065 & 0.176 & 0.023 & 0.265 & 0.238 & 0.062 & 0.067 & 0.615 \\
TKW & -0.07 & -0.059 & -0.075 & 0.155 & 0.019 & 0.142 & 0.029 & 0.519 & 0.057 & 0.702 \\
YP & -0.0073 & -0.052 & -0.085 & 0.219 & -0.013 & 0.175 & 0.145 & 0.270 & 0.102 & 1.00 \\
\hline
\end{tabular}

Residual effect $=0.039$ and bold values are direct effect 
The high heritability does not necessarily mean that the character will have with high GA. But, wherever this association exists, additive gene effects are probably important (Mahla et al., 2003). In the present study, high heritability was associated with high GAM\% in case of YP, $\mathrm{PH}, \mathrm{CW}$, TKW, FEH, NKE, indicating that additive genes were important in determining these characters.

Genotypic selection may, therefore, be used for improving these characters. The character FEH, ED, PH, EL, NKRE, NKR, NKE, TKW, and CW had significant and positive correlated with YP. Among them, ten characters TKW showed the highest and positive direct effect followed by the NKR, ED, NKE, which were observed in the co-efficient analysis (Jakhar et al., 2017).

\section{Conclusion}

The analysis of variances, SCC and PA revealed significant differences among the lines with respect to the characters studied. High GCV and higher heritability of FEH, PH, EL, ED, NKRE, NKR, NKE, TKW, YP, and CW indicated the high potential for selection. The phenotypic coefficient of variation was higher than the GCV for all the yield contributing traits of maize, which indicated the high environmental influence on the studied characters. Correlation study revealed that $\mathrm{PH}$ had excellent correlation with YP. Considering all traits, IL-28, performed better followed by IL-9, IL-15, and IL-10. These important finding will help to find out the more diverse inbred lines in maize, which might be used in the hybridization program.

\section{Conflicts Interests}

The authors declare no conflicts of interest to publish this manuscript.

\section{Acknowledgments}

We are grateful to Institute of Research and Training (IRT) of Hajee Mohammad Danesh Science and Technology University, Dinajpur for providing financial support of the research work.

\section{References}

Afroz R, Sharif MSH and Rahman L. 2004. Genetic variability, correlation and path analysis in mustard and rape (Brassica spp.). Bangladesh J. Pl. Breed. Genet. 17(10): 59-63.

Ahmed M, Mian MA and Chowdhury MA. 2011. Correlation study in maize. J. Agric. Res. 16: 399-405.

Ali Q, Elahi M, Ahsan M, Tahir MHN and Basra SMA. 2012. Genetic Evaluation of Maize (Zea mays L.) Associations for Growth Related Seedlings Traits. IJAVMS. 6:164-172. https://doi.org/10.5455/ijavms.20110608051727

Allam CR, Jaiswal HK and Qamar A. 2015. Character association and path analysis studies of yield and quality parameters in basmati rice (Oryza sativa L.). The Bioscan. 9(4): 1733-1737.

Azad MAK, Biswas BK, Alam N and Alam SS. 2012. Genetic Diversity in Maize (Zeya mays) inbreed line. The Agriculturists. 10(1): 64-70.

BBS. 2016. Agriculture Marketing System in Bangladesh. http://www.fao.org/fileadmin/templates/ess/documents/apca s26/presentations/APCAS-16-5.2.5_-_Bangladesh__AMIS_in_Bangladesh.pdf
Bello OB Maliq A 2010. Correlation and path coefficient analysis of yield and agronomic characters among open-pollinated maize varieties and their $F_{1}$ hybrids in a diallel cross. African J. Biotech. 9(18): 2633-263.

Begum S, Ahmed A, Omy SH, Rohman MM and Amiruzzaman M. 2016. Genetic Variability, Character Association and Path Analysis in Maize (Zea mays L.). Bangladesh J. Agric. Res. 41: 173-182. https://doi.org/10.3329/bjar.v41i1.27682

Burton G W 1952. Quantitative inheritance in grasses. 6th International Grassland Congress. 1: 277-283.

Chaudhry AR. 1993 Maize in Pakistan. Punjab Agricultural Research. Coordination Board, University of Agriculture, Faisalabad, Pakistan.

Comstock RR, Robinson HF. 1952. Genetic parameters, their estimation and significance, proc. 6th international Grassland Congress. Vol. 1, Nat. Publ. Co. Wash., D.C., U.S.A., pp: 248-291.

DAE. 2012. Department of Agriculture Extension. Annual Report for 2011-12. Bangladesh Agricultural University, Mymensingh.

Dewey DR and Lu KH. 1959. A Correlation, Path Coefficient Analysis of Components of Crested Wheat Grass Seed Production. Agron. J. 51: 515-518. https://doi.org/10.2134 /agronj1959.00021962005100090002x

Farnia A and Mansouri M. 2015. Study on Morphological Characteristics of Maize (Zea mays L.) Cultivars under Different Plant Densities. Indian J. Natural Sci. 5(30): 83918397.

Garcia LF, del Moral Y, Rharrabti D, Villagas and Royo C. 2003. Evaluation of grain yield and its components in durum wheat under Mediterranean conditions: An oncogenic approach. Agron. J. 95: 266-274.

Gomez KA and Gomez AA. 1984. Statistical procedures for agricultural research (2nd.). John Wiley and sons, NewYork, $680 \mathrm{p}$.

Hanson CH, Robinson HF, Comstock RE. 1956. Biometrical studies of yield in segregation populations of Korean lespedeza. Agron. J. 48: 268-272.

Jakhar DS, Singh R and Kumar A. 2017. Studies on Path Coefficient Analysis in Maize (Zea mays L.) for Grain Yield and Its Attributes. Int. J. Current Microb. App. Sci. 6:28512856. https://doi.org/10.20546/ijcmas.2017.604.327

Johnson HW, Robinson HF, Comstock RE. 1955. Estimation of genetic and environmental variability in soybeans. Agron. J. 47: 314-318.

Khan R and Dubey RB. 2015. Combining ability analysis for nutritional quality and yield in maize (Zea mays L.). The Bioscan. 10(2): 785-788.

Khan FA, Ali S, Shakeel A, Saeed A and Abbas G. 2006. Genetic variability and genetic advance analysis for some morphological traits in B. napus L. J. Agric. Res. 44(2): 8388.

Mahla HR, Jambhulkar SJ, Yadav DK. and Sharma R. 2003. Genetic variability, correlation and path analysis in Indian maize (Zea mays L.). Indian J. Genet. Pl. Breed. 63(2): 171172.

Maruthi RT and Jhansi Rani K. 2015. Genetic variability, heritability and genetic 65 Variability and traits association in maize genotypes advance estimates in maize (Zea mays L.) inbred lines. J. App. Natural Sci. 7(1): 149 - 154.

Matin MQI, Uddin Md.S, Rohman Md.M, Amiruzzaman M, Azad AK and Banik BR. 2017. Genetic Variability and Path Analysis Studies in Hybrid Maize (Zea mays L.). American J. Pl. Sci. 8: 3101-3109. https://doi.org/10.4236 /ajps.2017.812209

Morris ML, Risopoulos J and Beck D. 1999. Genetic Change in Farmer- Recycled Maize Seed; a Review of the Evidence. CIMMYT Economics Working Paper No. 99-07. Mexico, D.F., CIMMYT. 1. 
Moulin S, Baret F, Bruguier N and Bataille. 2009. Assessing the Vertical Distribution of Leaf Chlorophyll Content in a Maize Crop. INRA Unite Climate, Soil, Environment (CSE), 7803 7929.

Omikunle OA, Oduwaye OA, Ajala MO and Ogunbayo SA. 2006. Heritability, character correlation and path coefficient analysis among six inbred lines of maize (Zea mays L.). World J. Agric. Sci. 2(3): 352-358.

Quayyum MA. 1993. Bhuttar Chash Paddhati (in Bengali). In: Chowdhury, M.K. and Islam, M.A., Eds., Bhuttar Utpadan O Babohar, Bangladesh Agricultural Research Institute, Gazipur, 43-48.

Rafique MR, Amer H, Tariq M and Abdul WA. 2006. Heritability and Interrelationship among grain yield and yield components in maize (Zea mays L.). Int. J. Agric. Biol. 6(6): $1560-8530$.

Sadek SE, Ahmed MA and Abd El-Ghaney HM. 2006 Correlation and Path Coefficient Analysis in Five Parents Inbred Lines and Their Six White Maize (Zea mays L.) Single Crosses Developed and Grown in Egypt. J. App. Sci. Res. 3: 159-167.

Shukla S, Bhargava A, Chatterjee A and Singh SP. 2004. Estimates of genetic parameters to determine variability for foliage yield and its different quantitative and qualitative traits in vegetable amaranth (A. tricolor). J. Genet. Breed. 58: 169-176.
Singh AK, Singh SK, Garg HS, Kumar R and Choudhary R. 2014. Assessment of relationships and variability of morphophysiological characters in bread wheat (Triticum aestivum L.) under drought stress and irrigated conditions. The Bioscan. 8(2): 473-484.

Singh RK and Chaudhary DB. 1985. Biometrical method in quantitative genetic Analysis Kalyani publishers, New-Delhi revised edition, India.

Uddin H, Rashid MHA and Akhter S. 2010. Relative Profitability of Maize Production under Different Farm Size Group in Kishoregonj District of Bangladesh. Progressive Agric. 21(1 \& 2): 247-248.

USDA. (United States Department of Agriculture) World Agricultural Supply and Demand Estimates Report of July 12, 2018. https://www.usda.gov/oce/commodity/wasde/ Secretary_Briefing.pdf

Wright S. 1923. Theory of path coefficient. Genet. 8: 239-255.

Yadav SK, Singh AK, Pandey P and Singh S. 2015. Genetic variability and direct selection criterion for seed yield in segregating generations of barley (Hordeum vulgare L.). American J. Pl. Sci. 6: 1543-1549.

Zaman MA and Alam M. 2013. Genetic Diversity in Exotic Maize (Zea mays L.) Hybrids. Bangladesh J. Agric. Res. 38(2): 335 . 